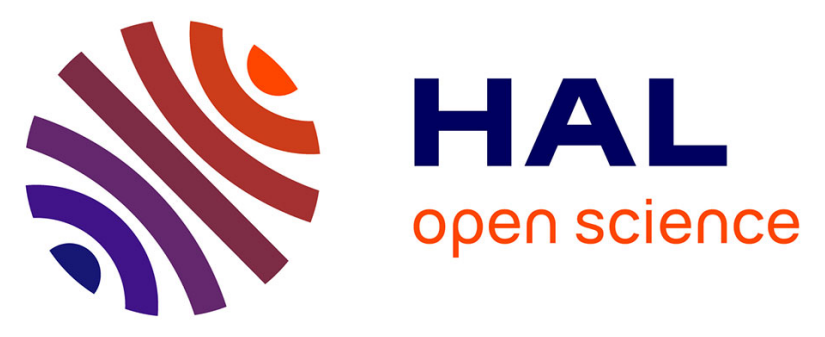

\title{
Germanium Dioxide and the Antioxidant Properties of Catechols
}

\author{
Elena N Nikolaevskaya, Artem V Kansuzyan, Galina E Filonova, Vera A \\ Zelenova, Valery M Pechennikov, Irina V Krylova, Mikhail P Egorov, \\ Viatcheslav Jouikov, Mikhail Syroeshkin
}

\section{To cite this version:}

Elena N Nikolaevskaya, Artem V Kansuzyan, Galina E Filonova, Vera A Zelenova, Valery M Pechennikov, et al.. Germanium Dioxide and the Antioxidant Properties of Catechols. European Journal of Inorganic Chemistry, 2019, 2019 (5), pp.676-681. 10.1002/ejic.201801259 . hal-01988895

\section{HAL Id: hal-01988895 \\ https://hal-univ-rennes1.archives-ouvertes.fr/hal-01988895}

Submitted on 22 Jan 2019

HAL is a multi-disciplinary open access archive for the deposit and dissemination of scientific research documents, whether they are published or not. The documents may come from teaching and research institutions in France or abroad, or from public or private research centers.
L'archive ouverte pluridisciplinaire HAL, est destinée au dépôt et à la diffusion de documents scientifiques de niveau recherche, publiés ou non, émanant des établissements d'enseignement et de recherche français ou étrangers, des laboratoires publics ou privés. 


\title{
Germanium dioxide and the antioxidant properties of catechols
}

\author{
Elena N. Nikolaevskaya, ${ }^{[a]}$ Artem V. Kansuzyan, ${ }^{[a, b]}$ Galina E. Filonova, ${ }^{[a, c]}$ Vera A. Zelenova, ${ }^{[a, c]}$ Valery \\ M. Pechennikov, ${ }^{[c]}$ Irina V. Krylova, ${ }^{[a]}$ Mikhail P. Egorov,${ }^{[a]}$ Viatcheslav V. Jouikov, ${ }^{* b]}$ and Mikhail A. \\ Syroeshkin ${ }^{*[a]}$
}

\begin{abstract}
Complexes of tetra- and hexa-coordinated germanium ${ }^{\mathrm{Adr}} \mathrm{Cat}_{2} \mathrm{Ge}\left(1,{ }^{\text {Adr }} \mathrm{Cat}=\right.$ adrenaline catecholate $),{ }^{\mathrm{Ald}} \mathrm{Cat}_{2} \mathrm{Ge}\left(2,{ }^{\text {Ald }} \mathrm{Cat}=\right.$ 4-formylcatecholate), ${ }^{\text {Ald }} \mathrm{Cat}_{3} \mathrm{Ge}\left(\mathrm{Et}_{3} \mathrm{NH}\right)_{2}$ (3) were synthesized by the reaction of germanium dioxide with adrenaline and 3,4dihydroxybenzaldehyde in aqueous solution. Structure of the first time prepared complexes was confirmed by ${ }^{1} \mathrm{H}$ and ${ }^{13} \mathrm{C}$ NMR and IR spectroscopy, HRMS and elemental analysis. Cyclic voltammetry in phosphate buffer solutions $(\mathrm{pH}=6.86)$ has shown the oxidation potentials $E_{p}$ of these complexes to be shifted by ca. $330-360 \mathrm{mV}$ to more positive potentials compared to the parent aromatic diols, meaning their ca. 7.6-8.3 $\mathrm{kcal} \mathrm{mol}^{-1}$ hampered electron releasing properties. Kinetics of the reaction of these complexes with 2,2diphenyl-1-picrylhydrazyl (DPPH) free radical in the presence of $5 \%$
\end{abstract}

\section{Introduction}

Free radical reactions are of high importance in the nature [1]. By initiating or inhibiting the formation of free radicals, the body regulates the destruction of the cell walls leading to the cell death. It is a mechanism for tissue renewal, disease control etc. By directly or indirectly ways the intensity of free radical processes is associated with aging [2].

An antioxidant system has been developed in the evolution process as a mechanism inhibiting radical damage ${ }^{[3]}$. In general, antioxidants are a large group of physiologically active compounds having enzyme ${ }^{[4]}$ or low molecular weight structures ${ }^{[5]}$ easily giving away an electron or otherwise chemically quenching the reactions of radicals ${ }^{[3]}$. As a rule, antioxidants are produced in the organism ${ }^{[6]}$ or enter with food ${ }^{[7]}$. It is worth to note that a lot of antioxidants have aromatic 1,2-diols (catechols) structure, which accounts for their easy oxidation ${ }^{[8]}$.

On the other hand, it is well known that catechols can "disassemble" a three-dimensional polymeric structure of germanium and silicon dioxides ${ }^{[9]}$ : two pincer hydroxyl groups of a diol form an efficient chelating site for $\mathrm{Ge}$ and $\mathrm{Si}$ able to bite

[a] Dr. E. N. Nikolaevskaya, A. V. Kansuzyan, G. E. Filonova, V. A. Zelenova, Dr. I. V. Krylova, Prof. Dr. M. P. Egorov, Dr. M. A. Syroeshkin

N. D. Zelinsky Institute of Organic Chemistry

Leninsky prosp. 47, 119991 Moscow (Russia)

E-mail: syroeshkin@ioc.ac.ru

[b] A. V. Kansuzyan, Prof. Dr. V. V. Jouikov

UMR CNRS 6226 ISCR

University of Rennes 1

35042 Rennes (France)

E-mail: vjouikov@univ-rennes1.fr

[c] G. E. Filonova, V. A. Zelenova, Dr. V. M. Pechennikov Pharmaceutical Department

I.M. Sechenov First Moscow State Medical University Moscow (Russia) acetonitrile reveals an approximately one order of magnitude decrease in the radical scavenging activity of adrenaline and model 3,4-dihydroxybenzaldehyde upon their complexation with $\mathrm{Ge}$. The corresponding rate constants drop from $(3.23 \pm 0.07) \times 10^{3} \mathrm{~L} \mathrm{~mol}^{-1} \mathrm{~s}^{-1}$ (adrenaline) to $(3.80 \pm 0.20) \times 10^{2} \mathrm{~L} \mathrm{~mol}^{-1} \mathrm{~s}^{-1}$ for 1 , and from $(4.40 \pm$ $0.20) \times 10^{3} \mathrm{~L} \mathrm{~mol}^{-1} \mathrm{~s}^{-1}$ (3,4-dihydroxybenzaldehyde) to (4.45 \pm $0.25) \times 10^{2} \mathrm{~L} \mathrm{~mol}^{-1} \mathrm{~s}^{-1}$ for 2 and 3 (germanium is equally capable to bind two or three molecules of the diol). Keeping in mind that 1,2diols are widespread in the living nature and often have important biological functions, these results will contribute to the understanding of role of germanium dioxide in metabolic mechanisms and to alert against unreasonable use of $\mathrm{Ge}$ preparations.

into these inert inorganic oxides transforming them in soluble monomeric and more reactive derivatives. Moreover, in case of germanium dioxide the reaction with catechol, known as Bevillard reaction ${ }^{[10]}$ (Scheme 1), can be carried out at low temperature in an aqueous medium. $\mathrm{GeO}_{2}$ dissolution in water has been investigated in detail by group of Prof. P. Pichet ${ }^{[11]}$. Here it is worth to note that biscatecholate silicon complexes are obtained with higher difficulty, but according to literature such products possess more Lewis acid activity which used in catalysis ${ }^{[12]}$.

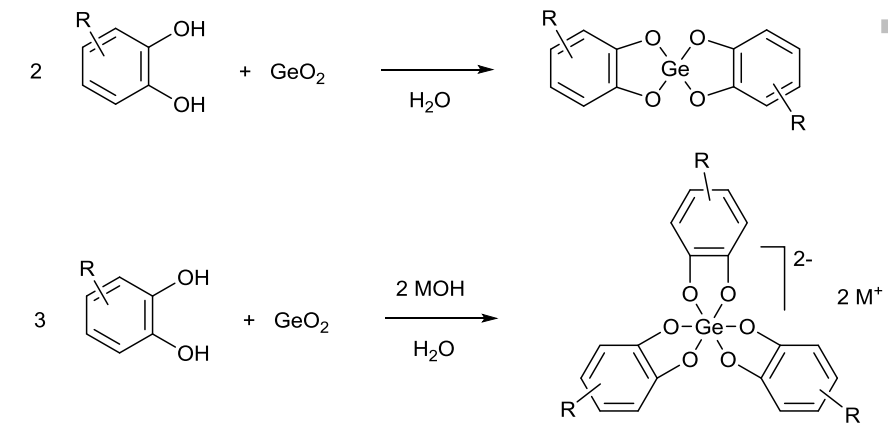

Scheme 1. Bevillard's reaction.

Generally, germanium is a physiologically active microelement that enters the body with food ${ }^{[13]}$. Compared to its congeners of the group 14, germanium and its derivatives have generally higher stability and lower tendency to hydrolysis. Several germanium derivatives are found in a number of popular dietary supplements ${ }^{[14]}$ in spite of a growing concern about their health hazard ${ }^{[15]}$. While their mechanism of action is not always clear ${ }^{[16]}$, their consumption was sometimes instigated by purely marketing reasons.

The present work aims to consider the previously undiscussed effect of germanium dioxide on the antioxidant properties of high biological relevance catechols from both 
thermodynamic and kinetic points of view. First assessment was realized using cyclic voltammetry, a standard method for evaluation of the ease of electron release ${ }^{[17]}$ through the shift of the redox potential E:

$$
\Delta \mathrm{G}=-\mathrm{n} F \mathrm{E}
$$

Another kinetic method for assessing the antioxidant properties is based on the estimation of the reaction rate of investigated antioxidant with 2,2-diphenyl-1-picrylhydrazyl (DPPH) free radical ${ }^{[18]}$.

\section{Results and Discussion}

It was found that Bevillard's reaction can occur in the case of adrenaline as well (Scheme 2). The corresponding complex 1 was obtained by the reaction of germanium dioxide with adrenaline (in 1:2 molar ratio) in aqueous solution.

$$
\text { (1/2) }
$$

Scheme 2. Synthesis of complex 1 .

The structure of complex 1 was established by IR and NMR spectroscopy and confirmed by HRMS and elemental analysis. In ${ }^{1} \mathrm{H}$ NMR spectra the peaks of $(\mathrm{HO}) \mathrm{C}-\mathrm{H}(4.66$ ppm), methylene (3.02 ppm) and methyl (2.61 ppm) groups are downfield shifted compared to the starting catecholamine $\left(\mathrm{CH} 4.44 \mathrm{ppm} ; \mathrm{CH}_{2}\right.$ dd, 2.49 and $2.52 \mathrm{ppm}$, $\mathrm{CH}_{3} \quad 2.29 \mathrm{ppm}$ ), while in ${ }^{13} \mathrm{C}$ NMR spectra the corresponding carbon signals of aforementioned groups are upfield shifted $\left(\mathrm{CH} 68.47\right.$ ppm; $\mathrm{CH}_{2} 54.94$ ppm; $\mathrm{CH}_{3} 32.69$ ppm vs $\mathrm{CH} 70.68$ ppm; $\mathrm{CH}_{2} 59.61$ ppm; $\mathrm{CH}_{3} 35.71 \mathrm{ppm}$ of non-coordinated adrenaline). The signals of aromatic protons are also shifted (from 6.55-6.72 ppm to 6.45-6.58 ppm). High resolution mass spectrum of the complex shows a group of peaks corresponding to the germanium species with its characteristic isotopic pattern (Fig. 1) ${ }^{[19]}$ ).

The antioxidant properties of complex 1 with respect to adrenaline were assessed by cyclic voltammetry in phosphate buffer solution $(\mathrm{pH}=6.86)$ under the conditions close to physiological (Fig. 2). The voltammograms of adrenaline show that its anodic peak reaching the maximum at $\mathrm{E}=0.51 \mathrm{~V}$ (vs. AgCl reference electrode) which correlates to strong antioxidant properties. On the reverse scan, the peak of reduction of adrenaline quinone is observed $^{[20]}$ (Scheme 2).

At the same time, on the voltammogram of 1 (Fig. 2b) a peak at $\mathrm{E}=0.84 \mathrm{~V}$ is observed. It corresponds to ca. 7.6 kcal $\mathrm{mol}^{-1}$ more difficult oxidation. Thus, according to

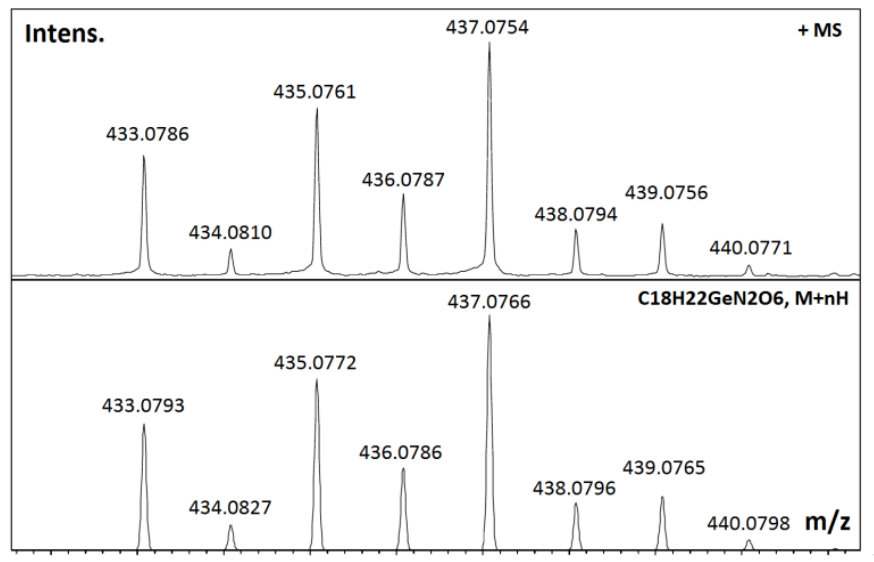

Figure 1. A fragment of the ESI-HRMS (positive ions) spectrum of $\mathbf{1}$ in $\mathrm{H}_{2} \mathrm{O} / \mathrm{CH}_{3} \mathrm{CN}$ (1:1): (top) experimental, (bottom) calculated.

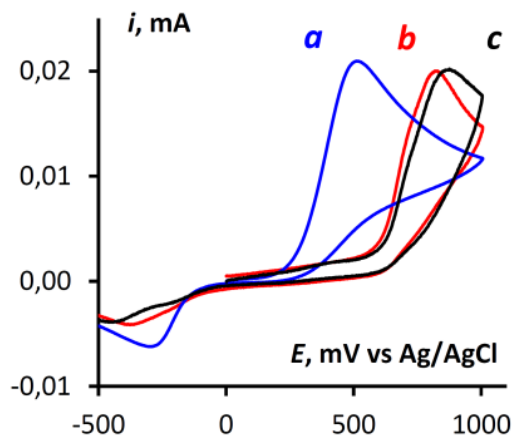

Figure 2. (a) Oxidation of adrenaline (2 $\left.\mathrm{mmol} \mathrm{L}^{-1}\right)$, (b) adrenalinegermanium complex $1\left(1 \mathrm{mmol} \mathrm{L}^{-1}\right)$, and (c) adrenaline- $\mathrm{GeO}_{2}$ mixture (2 $\left.+1 \mathrm{mmol} \mathrm{L}^{-1}\right)$ at a glassy carbon $(\mathrm{GC})$ disk electrode $(\mathrm{d}=1.7 \mathrm{~mm})$ in phosphate buffer $(\mathrm{pH}=6.86)$. Scan rate $\mathrm{v}=0.1 \mathrm{~V} \mathrm{~s}^{-1}$. $\mathrm{T}=298 \mathrm{~K}$.

voltammetry the interaction of adrenaline with $\mathrm{GeO}_{2}$ significantly weakens its antioxidant properties. Moreover, identical changes in the $\mathrm{CV}$ curves are observed when comparing the behavior of adrenaline and that of preliminarily prepared $\mathbf{1}$ (fig. 2a-b), or just adding a stoichiometric amount of $\mathrm{GeO}_{2}$ directly to the adrenaline solution (Fig. 2c).

The kinetics of the DPPH reaction with complex 1 was studied in phosphate buffer solution at $\mathrm{pH}=6.86$ (with $5 \%$ of $\mathrm{CH}_{3} \mathrm{CN}$ that was added because of poor solubility of DPPH in water). The UV spectrum of DPPH (Fig. 3) has a characteristic maximum at $\lambda_{\max }=530 \mathrm{~nm}$ in the visible region. In the presence of two-fold molar excess of adrenaline, the intensity of the aforementioned peak decreases by about 10 times after 30 seconds, illustrating strong antioxidant properties of adrenaline. A similar decrease is also observed in the presence of complex 1 but this time it took more than 4 minutes to attain the same effect. Kinetic analysis of quenching DPPH radicals with these antioxidants shows the rate constant decrease from $(3.23 \pm 0.07) \times 10^{3}$ to $(3.80 \pm 0.20) \times 10^{2} \mathrm{~L} \mathrm{~mol}^{-1} \mathrm{~s}^{-1}$, i.e. by almost 10 times when passing from adrenaline to its germanium complex 1. Thus, the interaction with $\mathrm{GeO}_{2}$ 

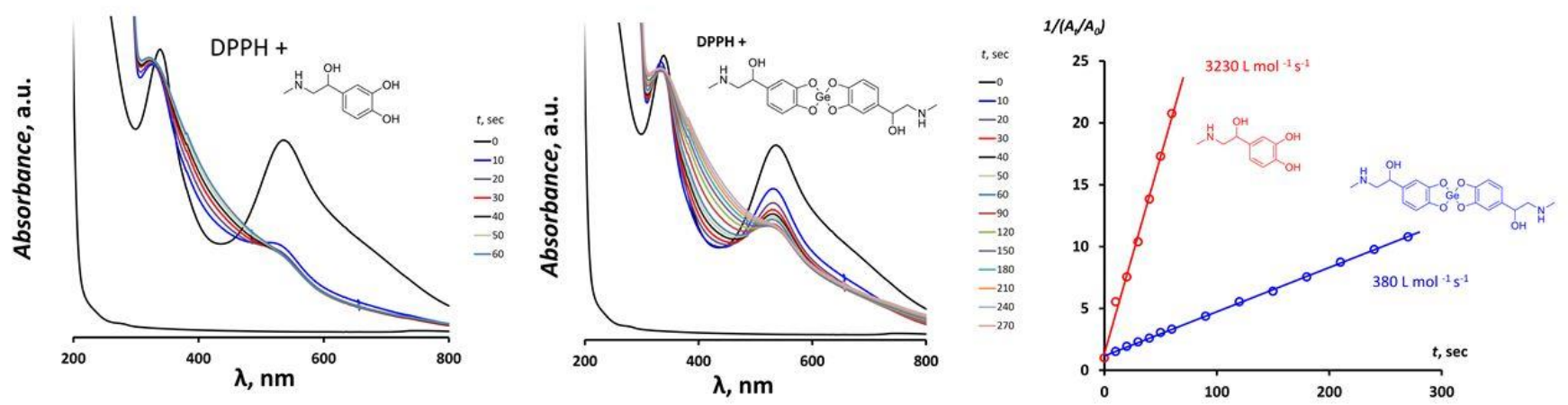

Figure 3. UV spectra of DPPH $\left(0.1 \mathrm{mmol} \mathrm{L}^{-1}\right)$ in phosphate buffer $(\mathrm{pH}=6.86)$ in the presence of (left) adrenaline $\left(0.2 \mathrm{mmol} \mathrm{L}^{-1}\right)$, (centre) adrenalinegermanium adduct $\left(0.1 \mathrm{mmol} \mathrm{L}^{-1}\right)$ and kinetic curves (right) of interaction of compound 1 and adrenaline with DPPH.

significantly impairs the antioxidant properties of adrenaline. Electron releasing ability of aromatic compounds, characterized by their redox potentials is strongly influenced by electronic properties of the substituent in the ring. Since adrenaline is a donor-substituted catechol, we were interested to investigate the effect $\mathrm{GeO}_{2}$ on the antioxidant properties of catechols with electron-withdrawing substituents. We have chosen for this purpose a catechol containing an aldehyde group at the 4-position of the benzene ring, 3,4-dihydroxybenzaldehyde.

It turned out that as in the previous case the Bevillard's reaction takes place efficiently and with a high yield (scheme 3).

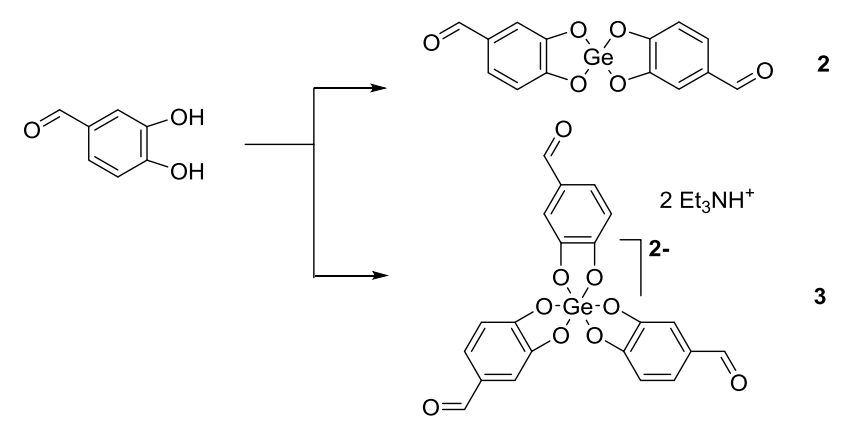

Scheme 3. Synthesis of complexes 2 and 3.

The structure of complex 2 was confirmed by elemental analysis, IR and NMR spectroscopy, and HRMS. By close analogy to complex $\mathbf{1}$, the ${ }^{1} \mathrm{H}$ NMR spectra of $\mathbf{2}$ show the peaks of aldehyde group (9.66 ppm) as well as of aromatic ring protons $(6.82,7.11$ and $7.22 \mathrm{ppm})$ to be shifted compared to the corresponding peaks of the starting cathechol (9.73 ppm for aldehyde group and 6.95, 7.28 and $7.30 \mathrm{ppm}$ for aromatic protons). Similar changes are observed in ${ }^{13} \mathrm{C}$ NMR spectra. HRMS (negative ion mass spectrum) of 2 reveals the signals corresponding to its dianion unit (Fig. 4)

The redox properties of 3,4-dihydroxybenzaldehyde and its germanium complex 2 were studied by cyclic voltammetry in phosphate buffer at $\mathrm{pH}=6.86$. On the cathechol's voltammograms anodic peak reaches the maximum at $\mathrm{E}=$

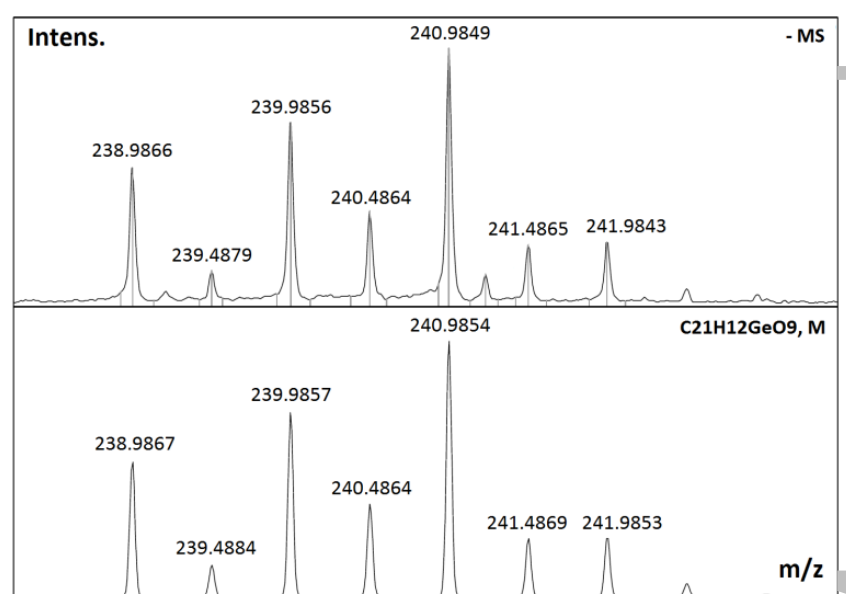

Figure 4. Fragments of the ESI-HRMS negative ion spectrum of 2 in $\mathrm{H}_{2} \mathrm{O} / \mathrm{CH}_{3} \mathrm{CN}$ (1:1): (top) experimental, (bottom) calculated.

$0.57 \mathrm{~V} \quad$ (Fig. 5). Unlike adrenaline, 3,4dihydroxybenzaldehyde does not have any reduction peak that could be attributed to the reduction of its quinone, which stems form the difference in the oxidation mechanisms of the two catechols.

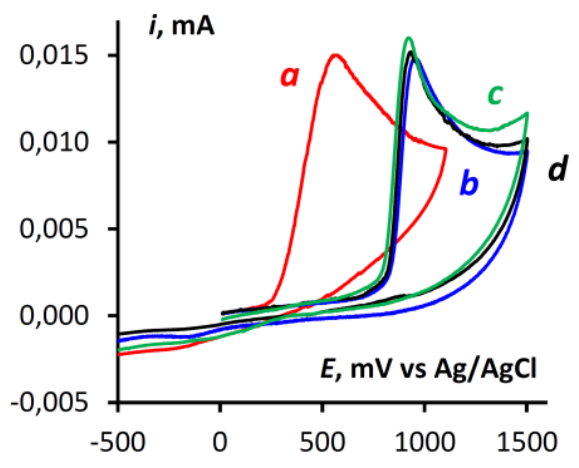

Figure 5. (a) Oxidation of 3,4-dihydroxybenzaldehyde (2 $\left.\mathrm{mmol} \mathrm{L}^{-1}\right)$, (b) 3,4dihydroxybenzaldehyde-germanium bis- $2\left(1 \mathrm{mmol} \mathrm{L}^{-1}\right)$, (c) tris-adduct 3 (0.67 $\left.\mathrm{mmol} \mathrm{L}^{-1}\right) \mathrm{GeO}_{2}\left(1 \mathrm{mmol} \mathrm{L}^{-1}\right)$, and (d) oxidation of 3,4-dihydroxybenzaldehyde $\left(2 \mathrm{mmol} \mathrm{L}^{-1}\right)$ after $5 \mathrm{~min}$ of stay in the presence of $\mathrm{GeO}_{2}\left(1 \mathrm{mmol} \mathrm{L}^{-1}\right)$. GC disk electrode $(\mathrm{d}=1.7 \mathrm{~mm})$, phosphate buffer $(\mathrm{pH}=6.86)$, scan rate $\mathrm{v}=0.1 \mathrm{~V} \mathrm{~s}^{-1}$, $\mathrm{T}=298 \mathrm{~K}$. 
The oxidation of 2 begins approximately $360 \mathrm{mV}$ more positive than the initial catechol. The peak has a potential of $0.93 \mathrm{~V}$. As in the previous case, the shape of the curve of the synthetically obtained sample 2 and the curve obtained after adding the stoichiometric amount of $\mathrm{GeO}_{2}$ directly to the catechol solution are identical. Comparative kinetics of the reaction of 3,4dihydroxybenzaldehyde and complex 2 with DPPH also showed a significant weakening of catechol antioxidant properties in the presence of $\mathrm{GeO}_{2}$ (Fig. 6). Whilst the catechol causes the concentration of the radical to drop more than 10 times within20 seconds, similar effect with 2 takes almost 4 minutes, which corresponds to the decrease in the rate constants from $(4.40 \pm$ $0.20) \times 10^{3}$ to $(4.45 \pm 0.25) \times 10^{2} \mathrm{~L} \mathrm{~mol}^{-1} \mathrm{~s}^{-1}$.

Bevillard's reaction lead to formation of hexacoordinated adducts in the presence of bases (Scheme 1). So the reaction of $\mathrm{GeO}_{2}$ with 3,4-dihydroxybenzaldehyde in molar ratio 1:3 followed by adding of two equivalents of $\mathrm{Et}_{3} \mathrm{~N}$ leads to product 3 . The obtained compound has been characterized by IR, NMR spectroscopy and mass-
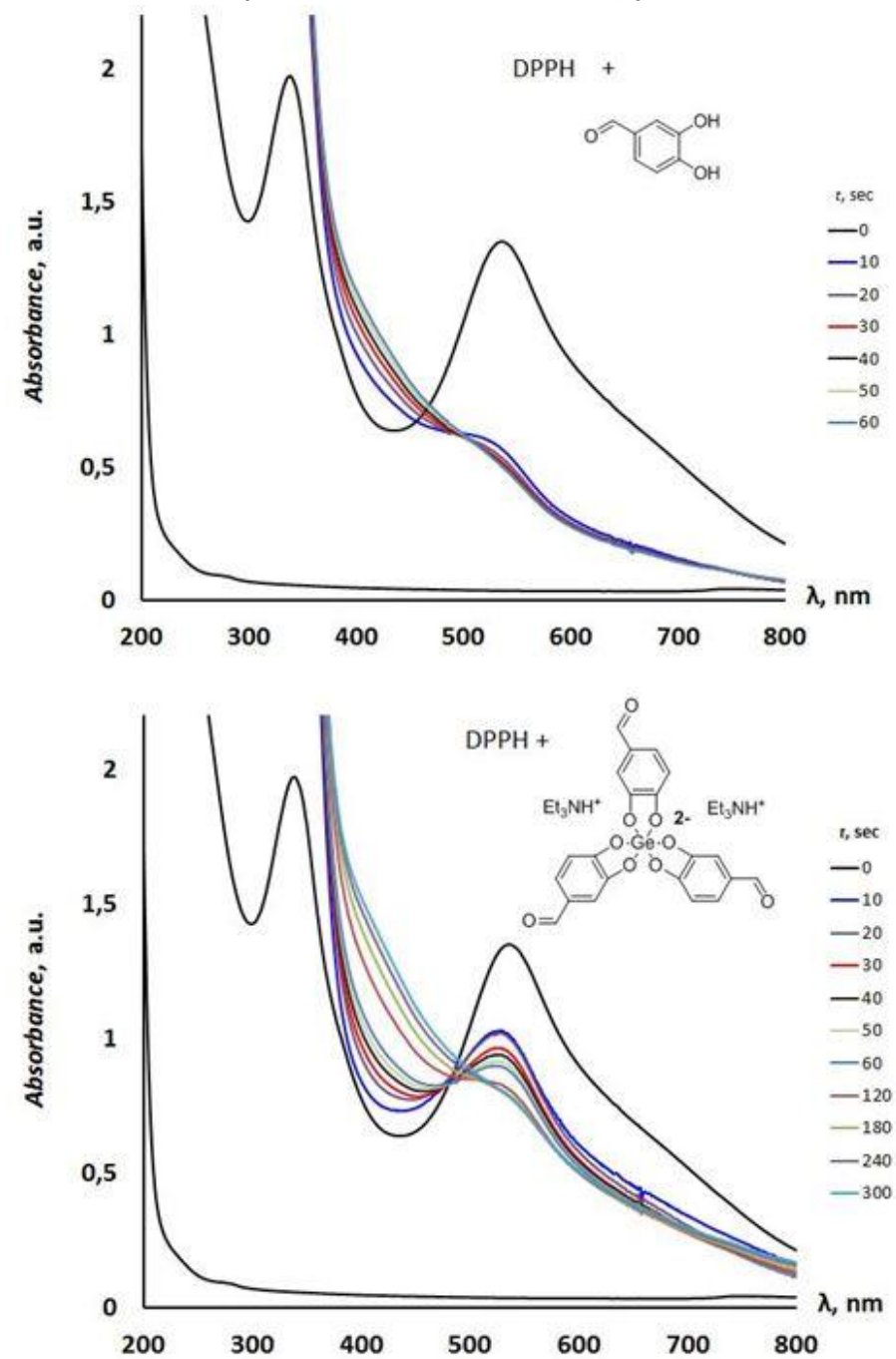

spectrometry. Attesting the complexation with $\mathrm{Ge}$, the $\mathrm{O}-\mathrm{H}$ vibration modes are absent in the IR spectra of 3 . The signal of the proton of aldehyde group in the ${ }^{1} \mathrm{H} N M R$ spectrum of $3(9.50 \mathrm{ppm})$ is upfield shifted compared to the non-coordinated 3,4-dihydroxybenzaldehyde (9.73 ppm). The signals of aromatic ring protons of $3(6.49,6.76$ and $7.01 \mathrm{ppm}$ ), similarly to the corresponding protons in 2 , are also upfield shifted compared to initial catechol $(6.95,7.28$ and $7.30 \mathrm{ppm}$ ), see Fig. 7. In addition, the signals of triethylammonium cation protons are observed at higher fields (1.18 and $3.04 \mathrm{ppm}$ ).

The voltammograms of $\mathbf{3}$ are very close to those of the bisadduct 2 (Fig. 5) (in all the cases presented, the results obtained with the ratio of the concentrations of catechol, bis- and trisadducts $3: 1.5: 1$ are given). The spectrophotometric study of the kinetics of reaction 3 with DPPH (Fig. 6) showed the rate constants very close (practically equal within the experimental error) to those with $\mathbf{2}$. Thus, germanium is equally capable to bind both two and three molecules of the catechol with an
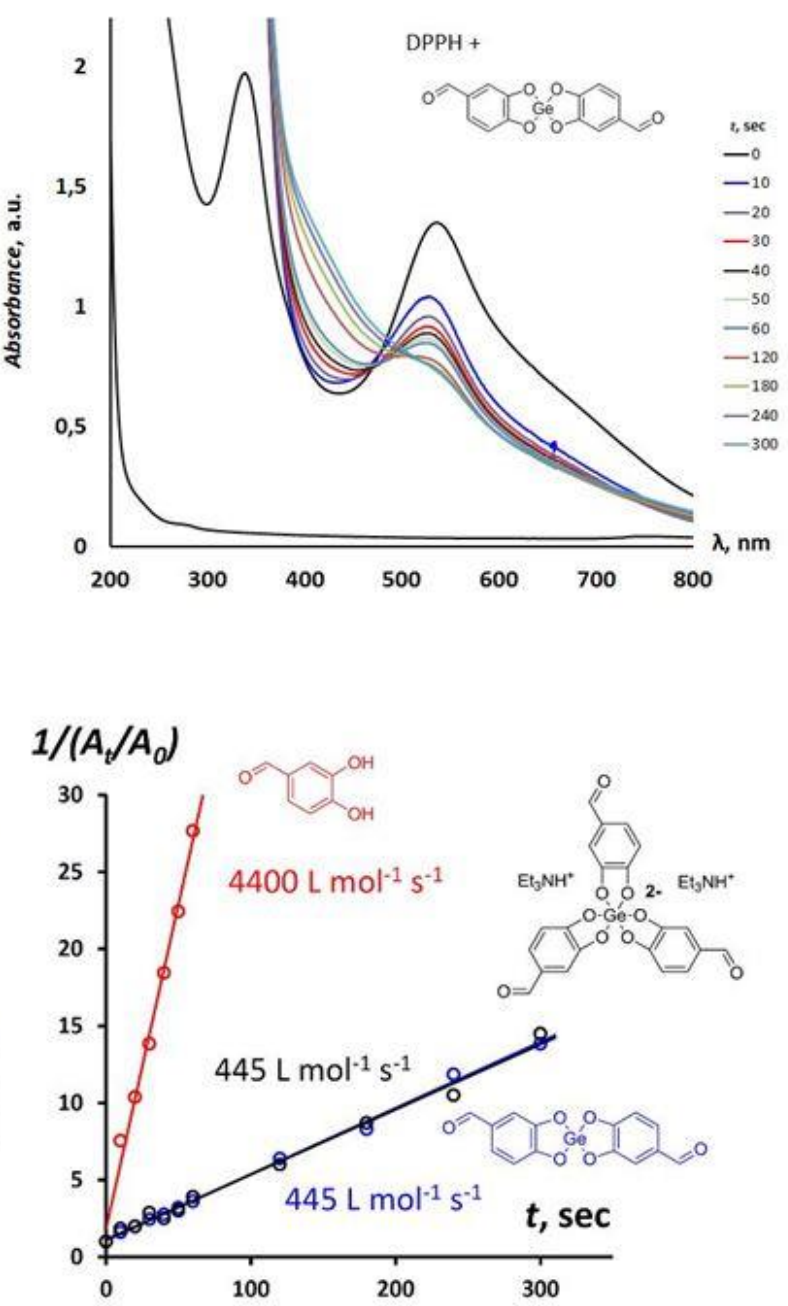

Figure 6. UV spectra of DPPH $\left(0.1 \mathrm{mmol} \mathrm{L}^{-1}\right)$ in phosphate buffer $(\mathrm{pH}=6.86)$ in the presence of (top, left) $3,4-$ dihydroxybenzaldehyde $\left(0.2 \mathrm{mmol} \mathrm{L}^{-1}\right)$, (top, right) 3,4-dihydroxybenzaldehyde-germanium bis- $\left(0.1 \mathrm{mmol} \mathrm{L}^{-1}\right)$, (bottom, left) tris-adduct $\left(0.067 \mathrm{mmol} \mathrm{L}^{-1}\right)$ and (bottom, right) kinetic curves of interaction of compounds 2, 3 and 3,4-dihydroxybenzaldehyde with DPPH. 


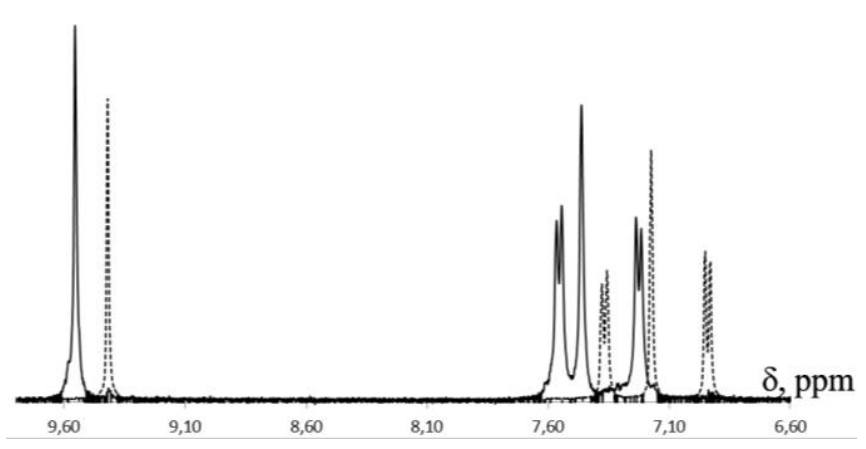

Figure 7. ${ }^{1} \mathrm{H}$ NMR spectra of 2 (line) and 3 (dotted line) in DMSO (300 $\mathrm{MHz}, 298 \mathrm{~K})$.

almost equivalent effect in reducing the antioxidant activity of the latter.

\section{Conclusions}

According to cyclic voltammetry and UV-Vis spectrophotometry, more difficult electron release and tenfold decrease reaction rates of catechols with DPPH free radical were found in the presence of $\mathrm{GeO}_{2}$. This study demonstrates that the presence of $\mathrm{GeO}_{2}$ in aqueous buffer solution at room temperature and at the $\mathrm{pH}$ close to physiological provokes a significant decrease of catechols antioxidant activity irrespectively the nature (donor/acceptor) of the substituents in their aromatic ring Together with the previous work devoting $\mathrm{Ge}$ food supplements as "antioxidant agents", these results can be considered as an alert that the uncontrolled uptake of germanium preparations might interfere with other functions of adrenaline and related biologic catechols as well. We hope that the present work would incite further study in this direction and help to make clear this so far unexplored aspect.

\section{Experimental Section}

$\mathrm{GeO}_{2}$ was purchased from "Germanium and Applications Ltd" (DG-B, TY 1774-001-95961127-2010, batch \#117). Adrenaline and 3,4dihydroxybenzaldehyde (Aldrich) were used without further purification. The solvents were purified by standard methods ${ }^{[21]}$. Buffer solutions $(\mathrm{pH}$ = 6.86) were purchased from Ecroskhim and dissolved in $1 \mathrm{~L}$ of distilled water before use. Thus prepared solution contained $3.389 \mathrm{~g}$ of $\mathrm{KH}_{2} \mathrm{PO}_{4}$ and $3.533 \mathrm{~g}$ of $\mathrm{Na}_{2} \mathrm{HPO}_{4}$.

${ }^{1} \mathrm{H}$ NMR $(300 \mathrm{MHz})$ and ${ }^{13} \mathrm{C}$ NMR $(75 \mathrm{MHz})$ spectra were recorded on a Bruker AM300 spectrometer in DMSO at ambient temperature using tetramethylsilane as an internal standard. FTIR spectra of the complexes were recorded on a BRUKER Vertex-70 FTIR spectrometer. Elemental analysis was done using an elemental Vario EL Element Analyzer. UVVis spectra were registered with Agilent 8453 instrument using a $10 \mathrm{~mm}$ quartz cell. Cyclic voltammetry was carried out using a PC-piloted digital potentiostat IPC-Pro-MF (Econix). A standard thermostated ( $T=25 \pm$ $\left.0.5{ }^{\circ} \mathrm{C}\right) 10 \mathrm{ml}$ electrochemical cell was used in a three-electrode configuration. As a working electrode, GC $(1.7 \mathrm{~mm})$ disk was used, polished before each run; a $\mathrm{Pt}$ wire was used as an auxiliary electrode. The potentials are referred to the $\mathrm{AgCl} / \mathrm{KCl}_{\text {sat }}$ electrode separated from the analyte by an electrolytic bridge filled with the same solution. In order to avoid any interference with the atmospheric oxygen, all measurements were carried out under argon.

High resolution mass spectra (HRMS) were measured on a Bruker micrOTOF II instrument using electrospray ionization (ESI) ${ }^{[22]}$. The measurements were done in a positive ion mode (interface capillary voltage $4.5 \mathrm{kV}$ ) or in a negative ion mode $(3.2 \mathrm{kV})$; mass range from $\mathrm{m} / \mathrm{z} 50$ to $\mathrm{m} / \mathrm{z} 3000$; external or internal calibration was done with ESI Tuning Mix, Agilent. A syringe injection was used for the solutions in acetonitrile/water 1:1 (flow rate $3 \mu \mathrm{L} / \mathrm{min}$ ). Nitrogen was applied as a dry gas; the interface temperature was set at $180^{\circ} \mathrm{C}$.

\section{General synthetic procedure}

\section{Complex 1:}

$\mathrm{GeO}_{2}(0.103 \mathrm{~g}, 0.1 \mathrm{mmol})$ and adrenaline $(0.358 \mathrm{~g}, 0.2 \mathrm{mmol})$ were placed in $30 \mathrm{~mL} \mathrm{H}_{2} \mathrm{O}$. The reaction mixture was then stirred with a magnetic stirrer for 8 hours. After then, the solution was concentrated on a rotary evaporator and $0.324 \mathrm{~g}(76 \%)$ of a colourless precipitate was obtained by prolonged cooling

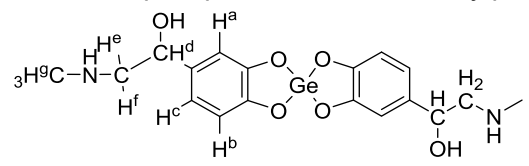

Anal. calc. for $\mathrm{C}_{18} \mathrm{H}_{22} \mathrm{GeN}_{2} \mathrm{O}_{6}$ : C, 49.70; H, 5.10; Ge, 16.70. Found C, 48.86; H, 5.67; Ge, 16.01. FTIR (KBr, $\left.\mathrm{cm}^{-1}\right): 442 \mathrm{w}, 651 \mathrm{~m}, 774 \mathrm{w}$ $811 \mathrm{~m}, 865 \mathrm{w}, 1067 \mathrm{w}, 1119 \mathrm{w}, 1165 \mathrm{w}, 1249 \mathrm{~s}, 1432 \mathrm{~s}, 1491 \mathrm{~s}, 1602 \mathrm{w}$ $1637 \mathrm{w}, 3416 \mathrm{~m} .{ }^{1} \mathrm{H}$ NMR (300 MHz, DMSO, $\left.\delta, \mathrm{ppm}\right): 2.61$ (s, 3H $\left.\mathrm{CH}_{3}{ }_{3}\right) ; 3.02\left(\mathrm{~d}, 2 \mathrm{H}, \mathrm{CH}^{\mathrm{e}-\mathrm{f}}{ }_{2}, \mathrm{~J}=8.25 \mathrm{~Hz}\right) ; 4.66\left(\mathrm{dd}, 1 \mathrm{H}, \mathrm{CH}^{\mathrm{d}}, \mathrm{J}\left(\mathrm{H}^{\mathrm{d}-\mathrm{e}}\right)=\right.$ $\left.8.3 \mathrm{~Hz}, \mathrm{~J}\left(\mathrm{H}^{\mathrm{d}-\mathrm{f}}\right)=4.3 \mathrm{~Hz}\right) ; 6.45-6.58\left(\mathrm{~m}, 3 \mathrm{H}, \mathrm{H}_{\text {arom }}\right) .{ }^{13} \mathrm{C}$ NMR $(50$ $\mathrm{MHz}$, DMSO, $\delta, \mathrm{ppm}): 32.69\left(\mathrm{CH}^{\mathrm{g}}{ }_{3}\right) ; 54.94\left(\mathrm{CH}^{\mathrm{ef}}{ }_{2}\right) ; 68.47\left(\mathrm{CH}^{\mathrm{d}}\right)$; $108.56 ; 110.20 ; 110.34 ; 134.53 ; 142.25 ; 143.33$.

\section{Complex 2:}

$\mathrm{GeO}_{2}(0.02 \mathrm{~g}, 0.25 \mathrm{mmol})$ and 3,4-dihydroxybenzaldehyde $(0.07 \mathrm{~g}$ $0.5 \mathrm{mmol}$ ) were added to $30 \mathrm{~mL} \mathrm{H}_{2} \mathrm{O}$. The reaction mixture was heated on a magnetic stirrer for 2 hours. After then, water was distilled off using rotary evaporator and the obtained residue has been washed 2 times $(\times 10 \mathrm{ml})$ with acetone to give $78 \mathrm{mg}(91 \%)$ of 2 as a colorless powder.

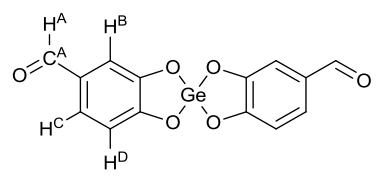

Anal. calc. for $\mathrm{C}_{14} \mathrm{H}_{8} \mathrm{GeO}_{6}$ : C, 48.76; $\mathrm{H}, 2.34 ; \mathrm{Ge}, 21.06$. Found: $\mathrm{C}$ 48.86; H, 2.27; Ge, 20.86. FTIR $\left(\mathrm{KBr}, \mathrm{cm}^{-1}\right): 1648 \mathrm{~s}, 1592 \mathrm{~s}, 1572 \mathrm{~m}$ 1491s, 1447s, 1408w, 1345w, 1273s, 1231m, 1160w, 1121m, $971 \mathrm{w}, 927 \mathrm{w}, 891 \mathrm{w}, 835 \mathrm{~m}, 814 \mathrm{~m}, 770 \mathrm{~m}, 701 \mathrm{~m}, 625 \mathrm{~m}, 593 \mathrm{w}, 575 \mathrm{w}$ 443w. ${ }^{1} \mathrm{H}$ NMR (300 MHz, DMSO, $\left.\delta, p p m\right): 6.82\left(\mathrm{~d}, 1 \mathrm{H}, \mathrm{H}^{\mathrm{C}}, \mathrm{J}=\right.$ $7.73 \mathrm{~Hz}$ ); $7.11\left(\mathrm{~s}, 1 \mathrm{H}, \mathrm{H}^{\mathrm{B}}\right) ; 7.22\left(\mathrm{~d} ., 1 \mathrm{H}, \mathrm{H}^{\mathrm{D}}, \mathrm{J}=7.73 \mathrm{~Hz}\right) ; 9.66(\mathrm{~s}$ $\left.1 \mathrm{H}, \mathrm{H}^{\mathrm{A}}\right),{ }^{13} \mathrm{C}$ NMR (300 MHz, DMSO, $\left.\delta, \mathrm{ppm}\right): 109.69 ; 111.81$; $125.21 ; 128.31 ; 149.38 ; 156.22 ; 191.37(-\mathrm{C}(\mathrm{O}) \mathrm{H})$

\section{Complex 3:}


$\mathrm{GeO}_{2}(0.035 \mathrm{~g}, 0.33 \mathrm{mmol})$ and 3,4-dihydroxybenzaldehyde $(0.134$ $\mathrm{g}, 1 \mathrm{mmol})$ were mixed with $30 \mathrm{~mL} \mathrm{H}_{2} \mathrm{O}$. Then $\mathrm{Et}_{3} \mathrm{~N}(0.092 \mathrm{ml}, 0.67$ $\mathrm{mmol}$ ) was added to the reaction mixture causing the solution color change to light yellow. After cooling, $0.177 \mathrm{~g}(81 \%)$ of 3 was isolated as a light yellow powder.

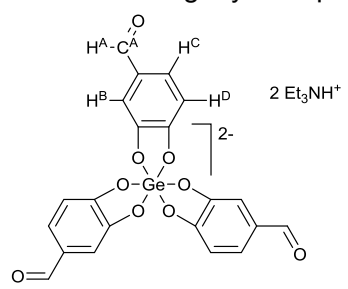

Anal. calc. for $\mathrm{C}_{31} \mathrm{H}_{44} \mathrm{GeO}_{9} \mathrm{~N}_{2} \cdot 3 \mathrm{H}_{2} \mathrm{O}$ : C, 52.05; $\mathrm{H}, 7.05 ; \mathrm{N}, 3.92$. Found: C, 51.98; $\mathrm{H}, 6.39 ; \mathrm{N}, 3.71$. FTIR $\left(\mathrm{KBr}, \mathrm{cm}^{-1}\right): 422 \mathrm{~m}, 598 \mathrm{w}$, $631 \mathrm{~m}, 661 \mathrm{~m}, 765 \mathrm{~m}, 793 \mathrm{w}, 824 \mathrm{w}, 873 \mathrm{w}, 970 \mathrm{w}, 1033 \mathrm{w}, 1116 \mathrm{~m}$, $1159 \mathrm{~m}, 1231 \mathrm{~s}, 1264 \mathrm{~s}, 1343 \mathrm{~m}, 1398 \mathrm{~m}, 1443 \mathrm{~s}, 1490 \mathrm{~s}, 1565 \mathrm{~m}$, 1584s, 1664s, 3449br.s. ${ }^{1} \mathrm{H}$ NMR (300 MHz, DMSO, $\delta$, ppm): 1.18 (t, $18 \mathrm{H},-\mathrm{CH}_{2}-\mathrm{CH}_{3}, \mathrm{~J}=7.23 \mathrm{~Hz}$ ); 3.04 (q, $12 \mathrm{H},-\mathrm{CH}_{2}-\mathrm{CH}_{3}, \mathrm{~J}=7.23$ $\mathrm{Hz}) ; 6.49$ (d., $\left.3 \mathrm{H}, \mathrm{H}_{\text {arom, }} \mathrm{J}_{\mathrm{C}-\mathrm{D}}=7.75 \mathrm{~Hz}\right) ; 6.76\left(\mathrm{~s}, 3 \mathrm{H}, \mathrm{H}^{\mathrm{B}}\right) ; 7.01(\mathrm{~d}$, $\left.3 \mathrm{H}, \mathrm{H}_{\text {arom }}, \mathrm{J}_{\mathrm{D}-\mathrm{C}}=7.75 \mathrm{~Hz}\right) ; 9.50(\mathrm{~s}, 3 \mathrm{H},(-\mathrm{C}(\mathrm{O}) \mathrm{H})) .{ }^{13} \mathrm{C}$ NMR $(300$

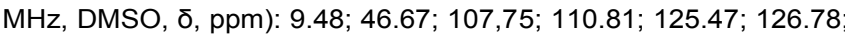
$152.45 ; 160.37 ; 191.34(-\mathrm{C}(\mathrm{O}) \mathrm{H})$

\section{Acknowledgements}

This work was supported by Grant MK-755.2017.3. High resolution mass spectra were recorded in the Department of Structural Studies of Zelinsky Institute of Organic Chemistry, Moscow.

Keywords: germanium dioxide $\cdot$ catechols $\cdot$ antioxidants $\bullet$ cyclic voltammetry $\cdot \mathrm{DPPH}$ test

[1] B. Halliwell, J. M. C. Gutteridge, Free Radicals in Biology and Medicine, Oxford University Press, 2015, p. 30-284, ISBN 9780198717478.

[2] H. Nohl, Br. Med. Bull. 1993, 49, 653-667.

[3] a) R.A. Jacob, Nutrition Research 1995, 15, 755-766; b) J. LimónPacheco, M. E. Gonsebatt Mutation Research/Genetic Toxicology and Environmental Mutagenesis 2009, 674, 137-147; c) J. Lu, A. Holmgren, Free Radical Biology and Medicine 2014, 66, 75-87.

[4] Z. B. Wang, Y. F. Wang, J. J. Zhao, L. Ma, Y. J. Wang, X. Zhang, Y. T. Nie, Y. P. Guo, L. X. Mei, Z. Y. Zhao, Photosynthetica 2018, 56 1081-1092.

[5] M. Wiciarz, E. Niewiadomska, J. Kruk, Photosynthetica 2018, 56 811-819.
[6] E. Birben, U. M. Sahiner, C. Sackesen, S. Erzurum, O. Kalayci, World Allergy Organ J. 2012, 5, 9-19.

[7] a) V. Lobo, A. Patil, A. Phatak, N. Chandra, Pharmacogn Rev. 2010 4, 118-126; b) S. Vertuani, A. Angusti, S. Manfredini, Curr Pharm Des. 2004, 10, 1677-1694.

[8] C. Ortega-Moo, J. Garza, R. Vargas, Theoretical chemistry accounts 2016, 135:177.

[9] a) K. Y. Blohowiak, D. R. Treadwell, B. L. Mueller, M. L. Hoppe, S Jouppi, P. Kansal, K. W. Chew, C. L. S. Scotto, F. Babonneau, J. Kampf, R. M. Laine, Chem. Mater. 1994, 6, 2177-2192; b) A Boudin, G. Cerveau, C. Chuit, R. J. P. Corriu, C. Reye, Organometallics 1988, 7, 1165-1171; c) P.D. Lickiss, R. Lucas, Polihedron 1996, 15, 1975-1979.

[10] P. Bevillard, Bull. Soc. Chim. Fr. 1954, 296-300.

[11] P. Pichet, R.L. Benoit, Inorg. Chem., 1967, 6, 1505-1509.

[12] a) R. Maskey, M. Schadler, C. Legler, L. Greb, Angew. Chem Int. Ed. 2018, 57, 1717-1720. DOI: 10.1002/anie.201712155; b) P. Guillo, M.I. Lipschutz, M.e. Fasulo, T.D. Tilley, ACS Catalysis, 2017, 7, 2303-2312. DOI: 10.1021/acscatal.7b00020.

[13] E. Lukevics, L. Ignatovich, Biological activity of organogermanium compounds, Ch. 23, in The Chemistry of Organic Germanium, Tin and Lead Compounds. V. 2, Ed. Z. Rappoport, John Wiley \& Sons, 2002, pp. 1653-1683.

[14] B. H. C. Stricker, Lancet 1991, 337, 864-864.

[15] S.-H. Tao, P.M. Bolger, Hazard assessment of germanium supplements, Regul. Toxicol. Pharmacol. 1997, 3, 211-219.

[16] A. A. Vishtorskaya, E. A. Saverina, V. M. Pechennikov, I. V. Krylova, A. V. Lalov, M. A. Syroeshkin, M. P. Egorov, V. V. Jouikov, J. Organomet. Chem. 2018, 858, 8-13

[17] a) J. Hoyos-Arbelaez, M. Vazquez, J. Contreras-Calderon, Food Chemistry 2017, 221, 1371-1381; b) J. Sochor, J. Dobes, O Krystofova, B. Ruttkay-Nedecky, P. Babula, M. Pohanka, T. Jurikova, O. Zitka, V. Adam, B. Klejdus, R. Kizek, Int. J. Electrochem. Sci. 2013, 8, 8464-8489; c) A. M. Pisoschi, C Cimpeanu, G. Predoi, Open Chem. 2015, 13, 824-856.

[18] a) C. Lopez-Alarcon, A. Denicola, Analytica Chimica Acta 2013, 763, 1-10; b) M. Carocho, I. C. F. R. Ferreira, Food Chem Toxicology 2013, 51, 15-25

[19] E. N. Tzanetou, K. M. Kasiotis, N. S. Thomaidis, E. Rosenberg, Current Analytical Chemistry 2013, 9, 244-249.

[20] A. C. Anitha, K. Asokan, C. Sekara, Electrochimica Acta, 2017, 237 44-53.

[21] D. D. Perrin, W. L. F. Armarego, D. R. Perrin, Purification of Laboratory Chemicals, Pergamon Press, Oxford, 1980.

[22] A. M. Tsedilin, A. N. Fakhrutdinov, D. B. Eremin, S. S. Zalesskiy, A O. Chizhov, N. G. Kolotyrkina, V. P. Ananikov, Mend. Comm. 2015 $25,454-456$ 


\section{FULL PAPER}

The presence of $\mathrm{GeO}_{2}$ in aqueous buffer solution at room temperature and at the $\mathrm{pH}$ closed to neutral (the conditions close to physiological) provokes a significant decrease in the antioxidant activity of catechols

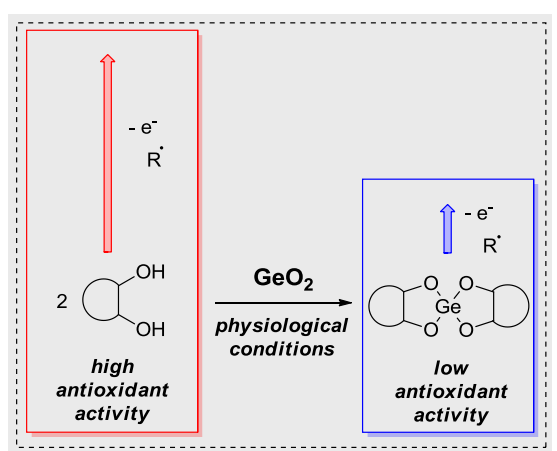

Elena N. Nikolaevskaya, Artem V.

Kansuzyan, Galina E. Filonova, Vera A

Zelenova, Valery M. Pechennikov, Irina

V. Krylova, Mikhail P. Egorov,

Viatcheslav V. Jouikov, ${ }^{*}$ and Mikhail A. Syroeshkin*

\section{Germanium dioxide and the} antioxidant properties of catechols 